\title{
NO ESPELHO DA POESIA
}

\section{IN THE MIRROR OF POETRY}

\author{
Ermelinda Maria Araújo Ferreira \\ Universidade Federal de Pernambuco
}

\section{RESUMO}

Este ensaio propõe uma aproximação preliminar e pouco comum das poéticas de Fernando Pessoa e Guimarães Rosa, a partir da análise de sua produção nos textos das "Ficções do Interlúdio", do português, e das "Coisas de Poesia", do brasileiro, considerando questões como o espaço literário, a desleitura da tradição canônica e a despersonalização do artista moderno.

PALAVRAS-CHAVE: Heteronímia pessoana; Poetas anagramáticos de Guimarães Rosa; Tradição Literária; Desleitura.

\begin{abstract}
This paper proposes a preliminary and unusual approach of Fernando Pessoa's and Guimarães Rosa's poetics, through the analysis of their production in the texts of the "Fictions of the Interlude", by the Portuguese author, and the "Poetry of Things", by the Brazilian one. We consider issues as the literary space, the misreading of the canonical tradition and the depersonalization of the modern artist.
\end{abstract}

KEYWORDS: Pessoa's heteronyms; Rosa's anagramatic poets; Literary Tradition; Misreading.

\section{NO JARDIM DOS AZULEJOS AMARELOS}

Cerca de grandes muros quem te sonhas Depois, onde é visível o jardim Através do portão de grade dada, Põe quantas flores são as mais risonhas, Para que te conheçam só assim.

Onde ninguém o vir não ponhas nada.

Faze canteiros como o que outros têm, Onde os olhares possam entrever

O teu jardim como lho vais mostrar. Mas onde é teu, e nunca o vê ninguém, Deixa as flores que vêm do chão crescer

E deixa as ervas naturais medrar.

Faze de ti um duplo ser guardado; E que ninguém, que veja e fite, possa

\footnotetext{
${ }^{*}$ Professora doutora do Programa de Pós-Graduação em Letras da Universidade Federal de Pernambuco. E-mail: ermelindaferreir@uol.com.br
} 
Saber mais que um jardim de quem tu és

Um jardim ostensivo e reservado,

Por trás do qual a flor nativa roça

A erva tão pobre que nem tu a vês...

Fernando Pessoa. Conselho

\begin{abstract}
Atrás de grade - os varões sumidos pela roseira-branca da qual os galhos, de lenho, em jeito espesso se torciam e trançavam - começava outro espaço. Dele, a primeira presença dando-se no cheiro, mistura de muitos. De maior lembrança, quando se juntavam: o das rosas-chá; o da flor-do-imperador, de todos o mais grato; o do manacá, que fragra vago a limão; o dos gaimbés, apenas de tardinha saído a evolar-se; e, maravilha, delas só, o das dracenas. Era um grande jardim abandonado. Seu fundo vinha com as árvores. Seu fim, o muro, musgoento. Sem gente, virara-se em matagalzinho, sílvula, pequena brenha. À expansa, nos canteiros, surgiam bruscas espécies, viajadas no ar: a daninha formosa, a meia praga, a rastejante viçosíssima, os capins que entrementes pululam. As próprias nobres plantas, de antes, desdormiam e deslavavam-se, ameaçadas em sua fresca debilidade. Afolham, regredidas, desmedidas, fecham-se em tufos. Do verdemais-verde ou do verde-negro, adivinham-se obscuras clareiras, recessos onde as borboletas vão-se. Murcha-se muito, lá. Mesmo as rosas demoradas, que em seus ramos mofam ou enferrujam, enroladas às vezes em teias de aranha.
\end{abstract}

Guimarães Rosa. Jardim Fechado

Azulejos Amarelos é um dos treze títulos elencados por Guimarães Rosa para o livro de "sortidos e retalhos" que elaborava antes de morrer. O termo azulejo designa uma peça de cerâmica de pouca espessura em que uma das faces é esmaltada e brilhante, podendo ser lisa ou em relevo, monocromática ou policromática. O azulejo é usado como revestimento arquitetônico ou como elemento decorativo isolado. Os temas podem ser ornamentais, com preponderância de motivos geométricos ou figurativos (animais, vegetais, frutas, flores); ou narrativos, oscilando entre os relatos de episódios históricos, cenas mitológicas, iconografia religiosa e alegorias diversas. Elemento decorativo cultivado em muitos países, tornou-se um importante suporte para a expressão artística portuguesa por mais de cinco séculos. Apesar de ter origem árabe e significar "pequena pedra polida", a palavra ąulejo costuma ser relacionada à palavra "azul" devido ao emprego majoritário desta cor na azulejaria portuguesa. Em português, a palavra é, por isso, considerada uma catacrese: metáfora antiga, desgastada, da qual se perdeu o sentido original.

Na obra rosiana, a "pedra de Araçuâ", um topázio, é recusada por Diadorim a Riobaldo, e vai parar como mimo nas mãos de Otacília. A palavra é derivada do grego topažos ("buscar"), nome de uma ilha de difícil acesso no Mar Vermelho, na qual uma pedra amarela era minerada em tempos antigos. $\mathrm{Na}$ Idade Média, o nome topázio era usado como referência a qualquer gema amarela. A fusão do azul da catacrese com o amarelo da transmutação alquímica (em Azulejos Amarelos) parece reinfundir ao termo, proposto como título possível para esse derradeiro e longamente meditado livro, algo da esperançosa força da metáfora primeva. Que acaba perdendo, contudo, na seleção do título pelo autor, para a oração Ave, Palavra.

Evocamos neste trabalho a opção Azulejos Amarelos, no entanto, pelo que ela sugere de relação direta com Portugal e com a antiga arte do mosaico, onde as imagens são produzidas pela colagem de múltiplos fragmentos sobre uma superfície. E evocamos esse livro por ele conter as quatro pequenas séries de poemas heteronímicos anagramáticos reunidos em torno do tema "Coisas de Poesia", que analisamos como uma provável citação, que gostaríamos de imaginar ser uma homenagem do escritor brasileiro Guimarães Rosa ao poeta português Fernando Pessoa. 


\section{Pseudonímia e Heteronímia ${ }^{1}$}

Não são frequentes, nas fortunas críticas desses autores, aproximações comparativas entre suas obras. Talvez porque nem Pessoa seja conhecido como grande prosador, apesar do monumental Livro do Desassossego; nem Rosa como grande poeta, apesar do premiado livro de estreia, Magma, e das pequenas e preciosas peças dispersas no livro Ave, Palavra; entre elas, o impressionante conjunto intersemiótico "O Burro e o Boi no Presépio" - para não mencionar a curiosa série das "Coisas de Poesia". Entretanto, aproxima esses autores uma mesma e indiscutível inclinação ocultista, responsável pelo hermetismo de muitas de suas produções; e a concepção do esoterismo como trajetória para o autoconhecimento, que não pode ser obtido pela via do intelecto e precisa ser acessado pela experiência sensorial e pela vivência afetiva. $\mathrm{O}$ poeta seria, assim, um tradutor, um intérprete de símbolos, capaz de apreender a linguagem cifrada do cosmos, recriando-a através da palavra.

Essa proximidade é traduzida por Rosa e Pessoa num contínuo jogo de afirmação/negação do sujeito, que oscila entre o mais narcísico solipsismo e a mais plural dispersão de personalidades, entre a percepção do eu-sozinho e a percepção dos outros-em-mim, angústia que é responsável, em ambos os casos, pelo caráter enigmático que distingue suas obras. Perpassadas por um sopro mágico, a palavra pessoana e a palavra rosiana são percebidas com profundo estranhamento pelo leitor. A intencionalidade dessas poéticas, bem como a familiaridade que estabelecem entre si, podem ser percebidas nos textos em epígrafe, "Conselho" e "Jardim Fechado", os quais utilizam a mesma metáfora botânica, descrevendo em perfeita sintonia o que deve e o que não deve ser dito.

Atrás das grades dos portões e facultadas à visão exterior, cultivadas simulações de exuberância, perfume e cor, condizentes com as expectativas dos curiosos. Para mais além, no íntimo e secreto do ser, no outro espaço ou na clareira próxima aos altos muros musgoentos do fim, nada. No máximo, ervas naturais: brenhas, daninhas, pragas, capins. Regredidas, desmedidas e fechadas em tufos. Inacessíveis, pois. São poéticas sub-rosa: que denotam segredo ou confidencialidade, inspiradas na flor que é o emblema do deus egípcio Hórus, Harpócrates em grego, considerado o deus do silêncio - assinalada no sobrenome de um e na provável afiliação de ambos, iniciática ou não, mas nunca assumida, ao Rosacrucianismo.

Qualquer escrutinador desses jardins estaria, pois, desde o início, fadado a vislumbrar apenas o que deles se revela, e a escutar sobretudo o silêncio que emana do mistério: não tanto daquilo que não deve ser dito, mas daquilo que não pode ser dito pelos jardineiros. Entretanto, o combate dos poetas com o mistério que reclama uma voz, e por essa mesma voz é traído, é tão antigo como o homem que, através da linguagem, separou-se do mundo e de si mesmo como unido ao ritmo da criação. Uma tal separação, embora seja intrínseca à natureza humana:

permanece como que indivisível ao nível da existência inautêntica que crê coincidir com a expressão que a manifesta. A linguagem é então "a coisa", e a solidez das coisas empresta ao rumor dos lábios o peso da sua aparência. [...] A ocasião chegará em que o homem privilegie o silêncio original, o anterior silêncio de onde as palavras nascem sem poder exprimir nem tocar a verdadeira realidade. Plotino dirá que o falar é a sanção de uma decadência da perfeição original e os místicos de todos os tempos far-se-ão eco desta opinião plotiniana. Pode dizer-se que não falam senão para recomendar o silêncio. (LOURENÇO, 2008, p. 188)

\footnotetext{
1 Psendonimia: qualidade do psendônimo: nome(s) adotado(s) por autor ou responsável por uma obra (literária ou de qualquer outra natureza), que não usa o seu nome civil verdadeiro ou o seu nome consuetudinário, por modéstia ou conveniência ocasional ou permanente, com ou sem real encobrimento de sua pessoa. Heteronímia: estudo dos heterônimos: autores fictícios que possuem personalidades próprias e distintas da do autor que os constitui.
} 
Cremos, portanto, que é um mesmo e paradoxal movimento entre o solitário e o solidário, entre o querer e o não poder dizer, entre a tragédia da prisão em si e a angústia do desejo de libertação pelo outro o que mais de perto aproxima as escrituras que documentam as existências desses autores, no espaço dos 47 anos de Fernando Pessoa (1888-1935) e dos 67 anos de Guimarães Rosa (1908-1967). É, pois, nos coleios grafológicos de suas criações - imagens que representam a eternidade e o potencial divino - que tentaremos sondar as relações entre suas poéticas, a fim de dar notícia de alguns de seus possíveis intercâmbios, no breve espaço deste ensaio.

A enumeração de exemplos enantiomorfos nas obras rosianas é quase um lugar comum da crítica especializada, que a eles se refere como sugestivos de um aludido narcisimo do autor. $\mathrm{O}$ conto "Espelho", que separa as narrativas do livro Primeiras Estórias; a citação, nas iniciais dos títulos de três contos do livro Tutaméia, às iniciais de seu nome: JGR; e a presença enfática e plurilinguística do eu no nome do protagonista do conto "Cara de Bronze": Moi-me-ich-ego - que são algumas das alusões mais frequentemente mencionadas -, nem de longe dão conta da interminável lista de variações autorreferenciais ao nome próprio, à autoria e ao sujeito, dispersas em sua vasta produção, resumidas, talvez, na luminosa síntese "Tutaméia"(1967), seu último livro: "mea omnia". Há que se considerar ainda o indiscutível fascínio que o nome "João Guimarães Rosa" teria exercido num autor com inclinações místicas.

Em correspondência com o tradutor alemão Günter Lorenz, ele não se furtou a comentar essas intrigantes implicações etimológicas - diretamente ligadas às origens de seu idioma nativo, e às origens mesmas de Portugal, fundadas na arte da cavalaria: "Weihs Mahr", "cavaleiro combatente" ou "cavalo de combate", teria originado o termo "Wimara" ou "Guimara", forma primitiva de "Guimarães" - nome da cidade histórica considerada o berço da civilização portuguesa. Pequeno burgo fortificado no distrito de Braga, ao norte, era originalmente designada "Vimaranes", possivelmente um topônimo de Vimara Peres, personagem que, em meados do século IX, fez deste local o principal centro governativo do Condado Portucalense, que tinha conquistado ao Reino da Galiza.

Inspirando-se nesse conde, talvez, o escritor e autêntico fundador de um idioma genuinamente brasileiro - conquistado ao castiço português dos colonizadores com o poderoso auxílio dos dialetos sertanejos dos cavaleiros/vaqueiros das Minas Gerais - aproveita para se autodenominar, a partir das sugestões de seus sobrenomes: "O Cavaleiro da Rosa do Burgo do Coração", referindo-se a sua pequena terra natal, Cordisburgo, então ligada a Curvelo, na região central desse estado. Sugestivamente, o termo "Cavaleiro da Rosa" também remete ao movimento esotérico Rosacruz e ao grau 18 da Maçonaria - que pertence à categoria dos graus gnósticos e superiores, sendo consagrado à vitória da luz sobre as trevas, ao culto evangélico, ao advento de Cristo e à encarnação do Verbo.

O número 8, graficamente traduzido na lemniscata que representa o infinito na matemática, é um símbolo marcante para o autor. Semelhante às serpentes enroscadas no caduceu de Hermes/Mercúrio, símbolo da Medicina, esses hieróglifos aparecem nas ilustrações originais de Poty para a primeira edição de Grande Sertão: Veredas; e na própria indumentária do autor, sob a forma de uma gravatinha borboleta usada como ornamento. Também não lhe escaparam, naturalmente, as implicações esotéricas do nome "João", tanto pela referência ao Batista e ao Evangelista cristãos, como ao Hospitaleiro templário, patrono dos hospitais, e, portanto, ligado à área de formação do escritor - alusões que ele retoma em inúmeros desdobramentos na nomeação de sua imensa galeria de personagens.

Também não passa despercebida ao poeta português a ironia impressa em seu sobrenome. A sua pessoa nunca seria outra senão as suas máscaras, todas reais e nenhuma verdadeira, todas verdadeiras e nenhuma real. Alberto Caeiro, Ricardo Reis, Álvaro de Campos e Fernando Pessoa: "O mito do nada que é tudo", que no poema "Ulisses", de Mensagem, evoca, sem ardil, na apresentação do herói a Polifemo: “- Meu nome é Ninguém” (Personne), o fenômeno 
da abolição da identidade. Talvez estejamos diante de um mesmo procedimento com efeitos radicalmente diversos, onde a multiplicação pseudonímica de um remete invariavelmente à afirmação de um eu egolátrico, à sua assinatura de Autor; enquanto a proliferação heteronímica do outro mergulha no abismo da inexistência de um ego, transferindo a autoria de suas produções para uma pluralidade de seres, aos quais foram conferidos não apenas corpos (poéticos), aparências físicas e biografias, mas temperamentos, traduzidos em assinaturas próprias, autênticas e diversas, concebidas a adequação grafológica de seus manuscritos a outros critérios científicos e pseudocientíficos de classificação de identidades/personalidades em uso na época: como o seu alinhamento à tipologia prevista pela Teoria dos Humores de Hipócrates e Galeno (Sanguíneos, Fleumáticos, Coléricos e Melancólicos); e às notações de seus mapas astrológicos na cuidadosamente pensada configuração dos corpos celestes prevista para as datas dos nascimentos dessas criaturas. As caricaturas abaixo capturam bem essas especificidades dos autores, acentuando a satisfação de Rosa consigo mesmo e a inexistência de Pessoa para além de seus artifícios:
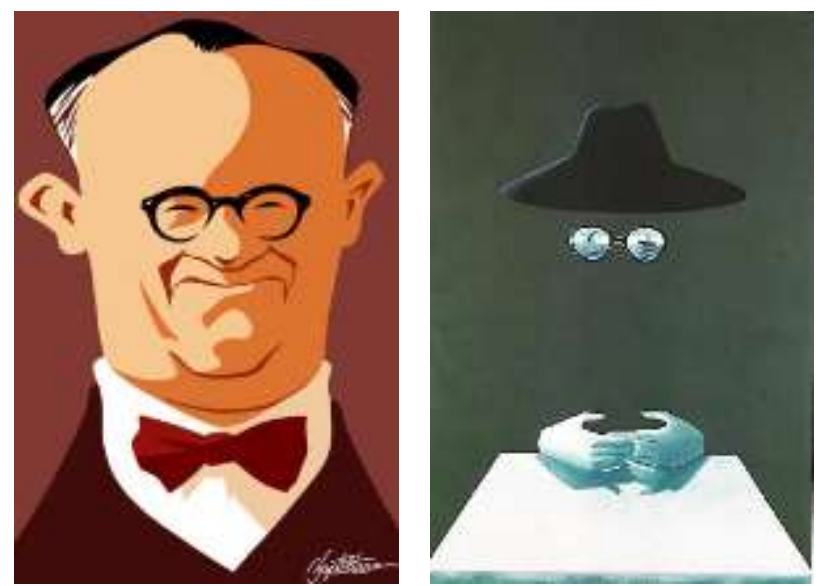

Lemniscatas caricaturais: a gravata borboleta de Guimarães Rosa, por Baptistão; e os óculos de Fernando Pessoa, por Costa Pinheiro.
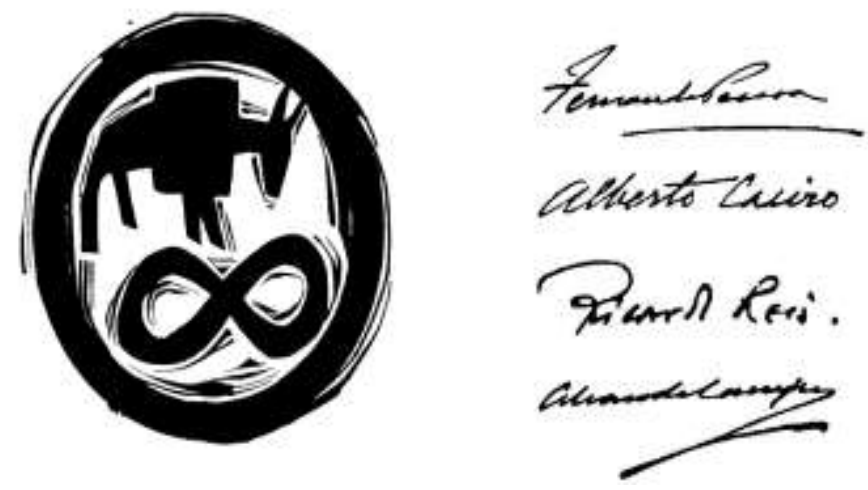

O símbolo de Grande Sertão: Veredas, por Poty, e as assinaturas concebidas para os heterônimos pessoanos, segundo suas personalidades e temperamentos, incluindo a assinatura do autor.

Parecem concordar as manifestações desses distintos desdobramentos egóicos, em ambos os autores, com a ideia de que o conhecimento deve estar fundado em estados de experiência interiores e pessoais, não se conseguindo estabelecer uma relação direta entre esses estados e o conhecimento objetivo de algo para além deles. O solipsismo do momento presente estende este ceticismo à noção de passado e de futuro, de tal modo que tudo o que resta é o eu presente. 
A neoescolástica define o solipsismo como uma forma de idealismo e imanentismo, que incorreria no egoísmo pragmático, uma vez que só se tem por certo e inconteste o ato de pensar e o próprio eu. Tudo o mais pode ser posto em dúvida.

Exemplo de uma reflexão solipsista - alegórica da criação heteronímica que constitui a marca da poética pessoana - aparece no chamado "drama estático" O Marinheiro. O tema é simples: três donzelas velam uma quarta, e durante o velório uma delas relata um sonho: a história de um marinheiro náufrago, desterrado numa ilha longínqua e sonhando ele próprio "uma pátria que nunca tivesse tido". A irrelevância do tema da peça para o autor é tamanha que, a certa altura do "diálogo", ele interroga, na voz de uma das veladoras: "Será absolutamente necessário, mesmo dentro do vosso sonho, que tenha havido esse marinheiro e essa ilha?"; e mais adiante, invertendo a perspectiva narrativa, e praticamente anulando a importância da cena do velório, que contém a própria veladora que fala e sonha: "Por que não será a única coisa real nisto tudo o marinheiro, e nós e tudo isto aqui um sonho dele?". Nesta peça em lemniscata, o poeta propõe sua concepção da vida como um teatro onírico, uma matrix criptografada ou uma projeção holográfica mental, que o poeta busca traduzir para o espaço bidimensional da escrita, desvendando o mistério do mundo pela negação de sua falsa tridimensionalidade e de seu falso movimento:

\begin{abstract}
Chamo teatro estático àquele onde as figuras não só não agem porque nem se deslocam nem dialogam sobre se deslocarem, mas nem sequer têm sentidos capazes de produzir uma ação; onde não há conflito nem perfeito enredo.[...] Creio que o enredo do teatro é, não ação nem a progressão e consequência da ação - mas, mais abrangentemente, a revelação das almas através das palavras trocadas e a criação de situações. (PESSOA, 1986 , p. 283)
\end{abstract}

"Teatro estático" é, na verdade, o que Pessoa desenvolve ao longo de sua obra poéticoperformática, da qual $O$ Marinheiro é uma das muitas alegorias - assim como são alegóricas as construções especulares e autocentradas que encontramos nos livros de Rosa. Isto se torna claro quando se atenta, em ambos os casos, na preocupação dramatúrgica desses escritores com o cenário, e mais do que ele, com o traçado do mapa do lugar onde serão encenados os seus dramas.

A crítica já ressaltou a importância simbólica da água, em sua dimensão oceânica, na obra pessoana: "Mar Português", por exemplo - uma das seções do livro Mensagem - usurpa ao mito Atlas, filho de Netuno e rei dos mares, o direito a renomear o "Atlântico", numa flagrante defesa da máxima camoniana em Os Lusíadas: "Cesse tudo o que a Musa antiga canta/Que um valor mais alto se alevanta". Da mesma forma, é conhecida a importância simbólica da terra, em sua imensidão desértica, na obra rosiana. As tentativas de travessia do "Liso do Sussuarão", rumando dos Gerais para os confins dos sertões baianos, abrem duas importantes veredas nesta obra eminentemente sertaneja. Na primeira, o grupo liderado por Medeiro Vaz sucumbe à hostilidade daquele "estralal do sol", retrocedendo com um saldo de homens e cavalos mortos. Na segunda, porém, sobrepujando a própria Natureza, o protagonista Riobaldo, após um pacto fáustico, consegue concluir a empresa iniciada pelo antigo comandante e dominar o "grande sertão". Em ambos os casos, têm-se um discurso hegemônico de afirmação identitária: sobre a hegemonia simbólica das divindades mitológicas greco-romanas, pelo poeta português; e sobre a hegemonia das divindades míticas autóctones e primitivas, pelo romancista brasileiro.

Mar e Sertão são, pois, os topoi geográficos, panos de fundo das realidades forjadas e "ficcionais" de Pessoa e Rosa, que adquirem para os seus criadores um status ontológico a partir do qual eles mesmos se definem e se percebem como seres no mundo. Em História Universal da Infâmia, Jorge Luis Borges resume essa questão em termos cartográficos. O mapa que coincide com os limites da realidade, entretanto, não encena, como se costuma interpretar, o fim da 
representação; mas o seu ápice - a tomada de consciência humana, como diz Gilles Deleuze, da precedência do simulacro ${ }^{2}$ na vida:

\begin{abstract}
Naquele império, a arte da cartografia alcançou tal perfeição que o mapa duma província ocupava uma cidade inteira, e o mapa do império uma província inteira. Com o tempo esses mapas desmedidos não bastaram e os colégios de cartógrafos levantaram um mapa do império que tinha o tamanho do império e coincidia com ele ponto por ponto. Menos dedicadas ao estudo da cartografia, as gerações seguintes decidiram que esse dilatado mapa era inútil e não sem impiedades entregaram-no às inclemências do sol e dos invernos. Nos desertos do oeste perduram despedaçadas ruínas do mapa habitadas por animais e mendigos; em todo o país não há outra relíquia das disciplinas geográficas. (BORGES, "Do Rigor na Ciência”, 1993, p. 95)
\end{abstract}

Num conto cuja temática é muito semelhante à de $O$ Marinheiro, Borges faz ainda um comentário que, aplicado ao processo de criação de Rosa e de Pessoa, parece muito elucidativo. Diz o narrador a respeito do protagonista:

O objetivo que o guiava não era impossível, ainda que sobrenatural. Queria sonhar um homem: queria sonhá-lo com integridade minuciosa e impô-lo à realidade. Esse projeto mágico esgotara o inteiro espaço de sua alma; se alguém lhe perguntasse o próprio nome ou qualquer traço de sua vida anterior, não teria acertado na resposta. (BORGES, “As Ruínas Circulares”, 1989, p. 40)

Talvez a expressão mais radical do solipsismo pessoano possa ser encontrada em Alberto Caeiro, o pastor amoroso que engendra como seu mestre pagão, e cuja obra o "acomete" em possessão no dia considerado "triunfal" de sua vida, quando redige ininterruptamente os versos do longo O Guardador de Rebanhos. Imediatamente em sequência - confessa -, emerge do espírito da contradição com o precursor a personalidade que passa a chamar "Fernando Pessoa". Numa curiosa estratégia, Pessoa transforma-se em discípulo de sua própria criatura; abdicando, portanto, do papel demiúrgico e de seu direito à precursividade no trato com Alberto Caeiro. Através da criação de um mito, e de sua eleição como mestre, Pessoa realiza o que para Harold Bloom representa o terrível paradoxo da Influência Poética - a inversão das origens -, que Borges trabalha tão bem em seu conto "Kafka e seus Precursores": "é o novo poeta ele mesmo quem determina a lei particular do precursor". Assim, Fernando Pessoa - o poeta do quarteto heteronímico - nasce no momento mesmo em que define esta lei:

E o que se seguiu foi o aparecimento de alguém em mim, a quem dei desde logo o nome de Alberto Caeiro. Desculpe-me o absurdo da frase: aparecia em mim o meu mestre. E tanto assim que, escritos que foram esses trinta e tantos poemas, imediatamente peguei noutro papel e escrevi, a fio, também, os seis poemas que constituem a Chuva Oblíqua de Fernando Pessoa. Imediatamente e totalmente... Foi o regresso de Fernando Pessoa Alberto Caeiro a Fernando Pessoa ele só. Ou melhor, foi a reação de Fernando Pessoa contra a sua inexistência como Alberto Caeiro. (PESSOA, 1986, p. 96)

Após o seu próprio nascimento heteronímico, segue-se o aparecimento das duas outras órbitas que irão compor a constelação corpoética que gira em torno do centro solar caeiriano:

2 “O simulacro não é uma cópia degradada, ele encerra uma potência positiva que nega tanto o original como a cópia, tanto o modelo como a reprodução. Pelo menos das duas séries divergentes interiorizadas no simulacro, nenhuma pode ser designada como o original, nenhuma como a cópia. Não basta nem mesmo invocar um modelo do Outro, pois nenhum modelo resiste à vertigem do simulacro. Não há mais ponto de vista privilegiado do que objeto comum a todos as pontos de vista. Não há mais hierarquia possível: nem segundo, nem terceiro. A semelhança subsiste, mas é produzida como o efeito exterior do simulacro, na medida em que se constrói sobre as séries divergentes e faz com que ressoem. A identidade subsiste, mas é produzida como a lei que complica todas as séries, faz com que todas voltem em cada uma no curso do movimento forçado.” (DELEUZE, 1974, p. 259) 
Ricardo Reis e Álvaro de Campos. No Prefácio às Fições do Interlúdio, Pessoa assinala a centralidade de Caeiro na deflagração desta poética:

\begin{abstract}
Referem os astrólogos os efeitos em todas as causas à operação de quatro elementos o fogo, a água, o ar e a terra. Com este sentido poderemos compreender a operação das influências. Uns agem sobre os homens como a terra, soterrando-os e abolindo-os, e esses são os mandantes do mundo. Uns agem sobre os outros homens como o ar, envolvendo-os e escondendo-os uns dos outros, e esses são os mandantes de alémmundo. Uns agem sobre os homens como a água, que os ensopa e converte em sua mesma substância, e esses são os ideólogos e os filósofos, que dispersam pelos outros as energias da própria alma. Uns agem sobre os homens como o fogo, que queima neles todo o acidental, e os deixa nus e reais, próprios e verídicos, e esses são os libertadores. Caeiro é dessa raça. Caeiro teve essa força. (PESSOA, 1986, p. 91)
\end{abstract}

O aspecto mais radical dessa montagem é aquele que transcende o fenômeno heteronímico e transforma Fernando Pessoa, sujeito histórico, numa ficção do poeta ortônimo. Sendo desnecessário criar para essa voz autoral um corpo, um nome e uma biografia, como foi feito para os demais, Fernando Pessoa-poeta utiliza-se dos dados biográficos de Fernando Pessoa-homem para compor a máscara de mais um personagem do drama que ele simultaneamente concebe, representa, dirige e assiste.

A natureza ígnea da influência exercida pelo "mestre" revela o porquê do poder de despersonalização dramática de Caeiro: a ele é atribuída a função de facilitar, nos outros, a manifestação de identidades diferentes; por isso a sua influência não pode ser um exercício de poder e de domínio, nem um ato de possessão espiritual ou ideológica. O demiurgo, para Pessoa, é o mais incompleto e provisório dos seres, porque a ele cabe, sobretudo, a tarefa de estimular nos outros a busca da liberdade, conseguida a partir do crescimento e autonomia individuais. A partir de Caeiro, descobrimos toda a disciplina mental que é própria de Ricardo Reis, toda a emoção que é característica de Álvaro de Campos, e toda a genialidade que teima em se revelar na figura de Fernando Pessoa, por mais artifícios que ele elabore para ocultar-se.

Completo o cenário, portanto, resta a Pessoa destruir seu precursor. Caeiro é, assim, a única dentre as suas criaturas que ele efetivamente faz morrer. Aspira, com isso, a que ele, como os mitos, não subsista; que a sua verdade não permaneça, não dure: viva. Caeiro é um personagem contraditório, um mito criado para desmistificar, simulação de origem e de verdade, cujas falas - inelutavelmente mergulhadas no paradoxo - rasuram-se no instante mesmo em que são pronunciadas. Saber se este Mestre é real ou fictício não interessa à Poesia, que se alimenta da eterna dúvida, da constante surpresa do olhar da criança no mundo, sonhando deuses que devem sonhar-nos. Assim como a Alice de Lewis Carroll que, visitando em sonhos o País dos Espelhos, descobre uma possibilidade inusitada: "- Se o Rei acordasse - acrescentou Tweedledum - você se apagaria - puff!, como a chama de uma vela. - É mentira! - exclamou Alice, indignada"; também Pessoa parece afirmar, indignado: "Que importa que Caeiro seja de mim, se assim é Caeiro?... Operando sobre mim mesmo, me livrou de sombras e farrapos, me deu mais inspiração à inspiração e mais alma à alma. Depois disto, assim prodigiosamente conseguido, quem perguntará se Caeiro existiu?...” (PESSOA, 1986, p. 91).

\title{
3. Meias-estórias e Magnificat: o homúnculo
}

Fernando Pessoa está atirado à fama como um osso aos cães e é preciso esperar que, envenenados pelo osso, os cães o larguem.

António Quadros. Fernando Pessoa - Iniciação Global à Obra 
Voltando ao "Jardim Fechado" de Guimarães Rosa, surpreendemos o menino, fugido da escola, passeando com um gato - também como Alice - nos fundos de seu "inconscienciocioso", e a estranha descoberta que faz por lá:

O menino se deitou com a cabeça. Quieto, também, o gato. Um para o outro olhavam. Oscilavam os amores-perfeitos, com seus bonequinhos pintados. O menino se ensimesmitava. $\mathrm{O}$ gato, às suas barbas. E, nisso, o menino, pasmo: via o que, no olho do gato. Um homem! - seu retrato, pupilado. O menino se voltou: nada de nada. Então, porém, um bem-te-vi cantou, ípsis-vérbis. E havia o homem, num ramo de jasmim-do-cabo... do tamanhinho de um dedo, o homenzinho de nada. $\mathrm{O}$ assombro. $\mathrm{O}$ menino se arregalava. Era um Pequeno-Mindinho? Tinha barba. Tinha roupa? Vestido à mágica. No meio do estupefazer, todinho ele se alumiava. - "Tulipas! Este pássaro delator..." curvando-se, petulou, saudava. O menino disse: - "Como você chama?" - gago. - "Te disse: não me dê nome..." - retrucou o fantasmago. - "Ou, então, dêe-me os muitos nomes: Mirlygus, Mestrim, Mistryl, Mirilygus. Sou o teu amigo." O menino estendeu a mão. - "Não me toque, cidadão, que há que sou do outro lado. ... Venho das ab-origens. Você também." O menino sacudiu a cabeça, em alguma muita coisa ele nem acreditava. - "Que é que o senhor faz?" Mirilygus, fulgifronte, sorriu em centro de sua luz: - "Eu vivo de poesia." O menino também sorriu, e se encorajou: -"Meu senhor homúnculo. - falou (claro que com outras palavras) -...este jardim é o meu? E o figurim respondeu: -"Não. O seu virá, quando amar." (ROSA, 2001, p. 353)

$\mathrm{Na}$ Quiromancia, o dedo indicador é associado a Júpiter e o polegar à Vênus. Simbolizam o casamento do masculino com o feminino, do céu com a terra. Rosa substitui o dedo polegar pelo mindinho na sua alusão ao texto considerado o primeiro conto de fadas inglês (The History of Thom Thumb, the Little), no qual o esperto Polegarzinho confunde um ogro trocando as coroas das filhas do malvado pelos chapéus de seus irmãos, conseguindo, assim, salvá-los. (Câmara Cascudo, em Contos Tradicionais do Brasil, menciona uma versão russa na qual o personagem é conhecido por Miudinho: "Dedo Mindinho"). Nos Mudrás - (da raiz mud, "alegrar-se"), gestos simbólicos feitos com as mãos no Yoga, significando selo, senha ou chave, e utilizados para penetrar determinados setores do inconsciente coletivo - o dedo mínimo está relacionado à alma e ao amor.

Ocultado sob a aparência inofensiva de uma fábula infantil, e mais uma vez afundado sob uma variedade pseudonímica, Rosa menciona deliberadamente o homúnculo ${ }^{3}$, alusão que assume como sua interferência no corpo da estória. O homúnculo era uma criatura outra, estranha, mas igualmente descrita como própria, um reflexo do menino no espelho de um olho felino: "seu retrato pupilado". O "Pequeno Mindinho" era um Mestrim: um mestre?... A mesma cena aparece duplicada no poema "Magnificat", de Pessoa/Campos, que oscila entre a elegia e a ode, e que se conclui com grande esperança e alegria - raras neste poeta e em seus pares - também anunciada pelo reflexo de si no olho de um gato:

Quando é que passará esta noite interna, o universo,

E eu, a minha alma, terei o meu dia?

Quando é que despertarei de estar acordado?

Não sei. O sol brilha alto,

Impossível de fitar.

As estrelas pestanejam frio,

3 O conceito de homúnculo (do latim homunculus, "homenzinho") tem sido evocado em diversos contextos. Na alquimia, foi usado pela primeira vez por Paracelso, para designar uma criatura de cerca de 12 polegadas de altura que, segundo ele, poderia ser forjada por meio de sêmen humano posto em uma retorta hermeticamente fechada e aquecida em esterco de cavalo durante 40 dias. A criação de homúnculos seria um dos principais objetivos desta antiga ciência, que também se debruçava sobre a transmutação de metais inferiores em ouro e sobre a descoberta da Pedra Filosofal, que garantiria a vida eterna. A alquimia sofreu grande influência da tradição religiosa judaica, e dos ensinamentos cabalísticos, que também previam a criação de um ser vivo artificial, o Golem. (ROOB, 2015, p. 358). Modernamente, o termo foi reivindicado pelo neurocientista canadense Wilder Graves Penfield, para definir o mapeamento da representação do corpo humano no cérebro. 
Impossíveis de contar.

O coração pulsa alheio,

Impossível de escutar.

Quando é que passará este drama sem teatro,

Ou este teatro sem drama,

E recolherei a casa?

Onde? Como? Quando?

Gato que me fitas com olhos de vida,

Quem tens lá no fundo?

É Esse! É esse!

Esse mandará como Josué parar o sol e eu acordarei;

E então será dia.

Sorri, dormindo, minha alma!

Sorri, minha alma: será dia!

(PESSOA, Álvaro de Campos, 2005)

Magnificat - a canção entoada por Maria pela celebração da graça de sua fecundação divina, também ecoa na "Canção de Siruiž" em Grande Sertão: Veredas, numa evocação de Sírius, a estrela mais brilhante do céu, consagrada no passado à deusa egípcia Ísis (esposa de Osíris e mãe de Hórus), e retomada pelo cristianismo para anunciar ao mundo o nascimento de Jesus: a mesma que teria apontado no céu, aos Reis Magos, o caminho do presépio (presente em Ave, Palavra no emblemático conjunto poético já mencionado). Essa estrela, mencionada outras vezes ao longo da obra do autor, também aparece em Ave, Palavra na figura da Madame de Syaïs, cujo nome palindrômico e foneticamente sugestivo designa estranha cartomante que, falha no exercício profissional e remunerado da premonição pelas cartas do Tarô, consegue salvar seu cliente da morte pela ponderação, solicitude e envolvimento real com a pessoa que a procura, mediante os conselhos expressamente citados de Emmet Fox, irlandês, líder espiritual do New Thought, corrente do século XIX, cujo "livrinho de seis páginas" (provavelmente aquele intitulado O Sermão da Montanha) é recomendado pelo autor no conto.

O convívio com homúnculos - ou como quer que se lhes chame - também reside no âmago do mistério da criação pessoana. Fenômeno originário de sua infância, documentado por familiares e por ele mesmo, surge no seu jardim sob a alcunha do "Chevalier de Pas", Cavaleiro do Nada, aos seis anos, e jamais o abandona. Pessoa torna-se, ao longo da vida, uma máquina de escrever cuja existência humana - cada vez mais diminuta e acidental - parece servir apenas para a projeção de outros.

Em seu ensaio "Kierkegaard e Pessoa, a Comunicação Indireta", Eduardo Lourenço comenta sobre a radical diferença do fenômeno heteronímico pessoano e os demais, frequentes na literatura. Sua reflexão nos parece muito oportuna para uma comparação entre os desdobramentos pseudonímicos rosianos e a multiplicidade performática do poeta português. Para Lourenço, o teatro da comunicação indireta nasce da presença simultânea, numa consciência, de necessidades antagônicas. "Se a comunicação direta é o sinal da inautenticidade, resta-nos descobrir um outro processo de comunicação, uma linguagem mascarada através da qual o laço escamoteado que nos religa ao Absoluto nos seja de novo presente." Assim:

A heteronímia/pseudonímia de Kierkegaard merece com mais propriedade o nome de "comunicação indireta". Os seus numerosos heterônimos e pseudônimos estão a serviço de uma estratégia superiormente concertada ou dirigida pelo ortônimo indiscutível que é o próprio Kierkegaard, consciente do abismo entre si e Deus, mas presente a si mesmo com a suprema opacidade de uma imperiosa personalidade, nisto mil vezes mais próximo de Unamuno - [e de Rimbaud, Mallarmé e Pirandello] - do que

\footnotetext{
${ }^{4}$ Como parte do seu método filosófico inspirado por Sócrates e pelos diálogos socráticos, a obra inicial do filósofo e teólogo dinamarquês Søren Kierkegaard (1813-1855) foi escrita sob vários pseudônimos, que apresentam cada um deles os seus pontos de vista distintivos e que interagem uns com os outros em complexos diálogos.
} 
de Pessoa. [...] Para poder tratar a questão da heteronímia de Pessoa sob a rubrica da despersonalização seria necessário supor uma como que anterior e superior existência ortônima em relação à qual os heterônimos fossem essa existência diminuída, acidental, sempre referenciada à 'vida verdadeira', como acontece na despersonalização. Simplesmente em Pessoa - e por isso o seu caso é tão extraordinário e a sua beteronímia tão diferente o "ele-mesmo" não goza de privilégio algum, senão o do registro civil. (LOURENÇO, 2008, p. 184/185; p. 193)

\section{Despersonalização e personificação na suposta homenagem de Rosa a Pessoa}

O que Você é grita tanto que não me deixa escutar o que Você diz...

Guimarães Rosa. "Fantasmas dos vivos"

O livro Ave, Palavra, publicado postumamente em 1970, foi cuidadosamente meditado por Guimarães Rosa. Fugindo à preponderância do gênero narrativo usado em suas anteriores publicações, dispersas entre contos, novelas e um romance, essa miscelânea reúne, além das habituais histórias, peças advindas de outros gêneros: crônicas, diários, dramas e o que chama a atenção: poesia. Sabe-se que a primeira incursão rosiana na literatura ocorreu no gênero lírico e foi reunida no livro Magma, detentor do prêmio da Academia Brasileira de Letras em 1936, ao qual o autor concorreu com o próprio nome, diferentemente do pseudônimo Viator que usaria no concurso da Editora José Olympio, em 1938, para o livro de contos Sagarana. Apesar de ter obtido o segundo lugar, a obra só seria publicada em 1946, e o livro Magma aguardaria mais: incríveis 61 anos para vir a público, em 1997.

Durante sua vida, Guimarães Rosa não mostrou qualquer interesse em publicar seus poemas de estreia, chegando a dizer em entrevista: "escrevi um livro não muito pequeno de poemas, que até foi elogiado. Passaram-se quase dez anos até eu poder me dedicar novamente à literatura. E revisando meus exercícios líricos, não os achei totalmente maus, mas tampouco muito convincentes". O silêncio sobre a obra poética deste autor, contudo, perdura. Não são muitas as investidas da crítica na análise deste e de outros textos do gênero, compilados em Ave, Palavra, obra cuja concepção, como já dissemos, demorou a ser nomeada.

Como Clarice Lispector, em A Hora da Estrela, os treze títulos possíveis elencados por Guimarães Rosa para a coletânea oferecem visões diferentes sobre a obra. Reunião de cinquenta e uma peças literárias, separadas 25 a 25 por uma sempre intermediária e especular narrativa intitulada "Pé-Duro, Chapéu-de-Couro", o livro apresenta alguns paralelismos curiosos. São oito narrativas de viagem que compõem um bestiário sobre Aquários ( 2 - Berlim e Nápoles) e Zoos (6 - Londres, Rio, Hamburgo, Hamburgo, Paris, Paris); Diários em Paris (2); narrativas temáticas sobre a Segunda Guerra Mundial e o Nazismo; releituras de histórias diversas ("A Cartomante", de Machado de Assis; "Chapeuzinho Vermelho", de Perrault, e outras histórias infantis); crônicas e diários; histórias alinhadas por um nome, "Evanira"; e o que se nos afiguram, intencionalmente dispersas entre os mais como brilhantes agulhas num palheiro, como já dissemos, duas fundamentais criações poéticas de grande importância metalinguística em sua obra: "O Burro e o Boi no presépio" e as cinco coletâneas dos heterônimos anagramáticos: "Às Coisas de Poesia", "Novas Coisas de Poesia", "Quando Coisas de Poesia", "Sempre Coisas de Poesia", "Ainda Coisas de Poesia".

Em 1997/1998, Walnice Nogueira Galvão publicou na Revista USP o artigo "Heteronímia em Guimarães Rosa", no qual se assinala, provavelmente pela primeira vez, a possível alusão do escritor mineiro ao poeta português Fernando Pessoa, na composição deste conjunto de versos: 
Em Ave, Palavra vão aparecer, e até com relativa fartura, aqueles poetas cujo esquivo perfil vínhamos perseguindo. Cada um deles tem uma pequena explicação, devidamente obscura, a seu respeito, num intróito mínimo que precede a publicação dos vários blocos. Nem de longe têm a personalidade própria e a detida complexidade que Fernando Pessoa deu a seus heterônimos, os quais até horóscopo vieram a ter. Mas a sombra desse poeta pode ser divisada à distância, sendo ele uma cause célèbre que nenhum letrado brasileiro ou português ignora. (GALVÃO, 1997/1998, p. 21)

A "heteronímia" forjada por Guimarães Rosa na série "Coisas de Poesia" tem muito de ironia, mas num sentido diferente das "Ficções do Interlúdio" de Pessoa. A ironia pessoana é autorreferencial: devastadora na demolição do sujeito que se descobre, reiteradamente, nada. Já a ironia rosiana cerca ferozmente a precursividade canônica que assombra os efebos brasileiros, candidatos a poetas fortes na ainda incipiente "tradição literária" de além-mar que se esforçam por erigir. Revela-se, pois, em muitos momentos, como contundentes, sintéticas e perversas desleituras dos antepassados portugueses, dos trovadores a Pessoa, padecendo inegavelmente de sintomas da angústia da influência, seja para o bem, seja para o mal. Talvez o desdobramento percebido em Rosa seja mais da ordem da "pseudonímia" do que propriamente da "heteronímia"; entretanto, para fins desta análise, utilizaremos a sugestão de Walnice Nogueira Galvão.

Vejamos o tom de gracejo com que o autor apresenta os seus "heterônimos", à maneira pessoana, fornecendo dados gerais de cada um nas epígrafes que abrem as suas breves coletâneas de versos:

De Soares Guiamar - despercebido, impresso, inédito, fora-de-moda - que queria livro, o "Anagramas", e disse palpites: Ser poeta é já estar em experimentada sorte de velhice. Toda poesia é também uma espécie de pedido de perdão. (ROSA, "Às Coisas de Poesia", in: Ave, Palavra, 2001, p. 82)

Perguntam-me por mais versos de Soares Guiamar. Não são possíveis. Ele agora para longe, certo à beira do Riachinho Sirimim, lugar de se querer bem. Tenho, porém, outro poeta de bolso: Meuriss Aragão. Jovem, sem jeito, em sua primeira fase, provavelmente extinta. Vejam, se serve. (ROSA, "Novas Coisas de Poesia", in: Ave, Palavra, 2001, p. 121)

Sá Araújo Ségrim - poeta comprido - é outro dos anagramáticos, de que hoje disponho. Se bem talvez um tanto discípulo de Soares Guiamar, sob leves aspectos, sofre só e sozinho verseja. Sei que pensa em breve publicar livro: o "Segredeiro", e do supracitado é, às vezes, o que prefiro. Será que conosco concordam? (ROSA, "Sempre Coisas de Poesia", in: Ave, Palavra, 2001, p. 148)

Se não firo a modéstia, direi, que Sá Araújo Ségrim, em geral, agradou. Por isso mesmo, volta, hoje, com novos poemas, que só não sei se escolhemos bem. Sendo coisas mui sentidas. Sendo o que ele não sabe da vida. Digam-me, o mais, amanhã. Leiam-no, porém. (ROSA, “Quando Coisas de Poesia”, in: Ave, Palavra, 2001, p. 234)

Outro anagramático é Romaguari Sães, o “embevecido", escondedor de poemas. No grupo, é considerado como um tanto diferente. Tem outra música. Tem um amor mais leve, originário, avançado. Disse, uma vez, em entrevista, que a poesia devia ser um meio de "restituir o mundo ao seu estado de fluidez, anterior, exempta". Aprovam-no? (ROSA, "Ainda Coisas de Poesia", in: Ave, Palavra, 2001, p. 295)

As apresentações do "grupo" de "anagramáticos" é feita por uma voz anônima - dramatis persona de um crítico literário, talvez - que se dirige ao leitor rotulando os poetas, analisando suas obras, citando suas máximas sobre poesia, revelando suas intenções e projetos literários e incitando o público à leitura e à avaliação dos versos ora publicados. Embora não forneça dados sobre o veículo das publicações, sabemos que foram divulgados no jornal $O$ Globo, ao longo do 
ano de 1961. A analogia com o projeto heteronímico pessoano é inegável, reproduzindo o modo como Pessoa descreveu os heterônimos na famosa carta a Adolfo Casais Monteiro de 13/1/1935; e como os pôs a dialogar e a criticar uns aos outros nos prefácios e posfácios de suas produções.

Como uma análise minuciosa dessa antologia anagramática não caberia no espaço deste ensaio, selecionamos alguns poemas para consideração, no intuito de ressaltar o aspecto da "desapropriação" ou "expropriação" de formas e temas da tradição sujeitos ao virulento revisionismo rosiano. É de Romaguari Sães a retomada das cantigas medievais, que ele chama de "Marjolininhas", sugerindo haver várias além das quatro reproduzidas na coletânea, pois a última é identificada como " $\left.(9)^{a}\right)$ ". Como se trata de um "escondedor de poemas", entende-se.

Talvez a alusão às úlceras de Marjolin - termo comumente referenciado à degeneração maligna de feridas crônicas não cicatrizadas ou cicatrizadas por segunda intenção, cujo epônimo se refere ao anatomista Jean Nicolas Marjolin, que primeiro descreveu esse tipo distinto de ferida (sem conhecimento da natureza neoplásica da lesão) - não seja de todo forçada. ${ }^{5}$ Evocamos a formação médica do autor e as suas anteriores alusões ao simbólico crustáceo: tanto no poema "Caranguejo", do livro de estreia Magma, como n“A Espantada Estória”, de Meuriss Aragão, que retoma a antilírica proposta:

\section{Caranguejo}

Caranguejo feiíssimo, monstruoso, que te arrastas na areia como a miniatura De um tanque de guerra... Gosto de ti, caranguejo, Câncer meu padrinho nas folhinhas, pois nasci sob as bênçãos do teu signo zodiacal... [...]

(ROSA, in: Magma)

\section{A Espantada Estória}

O relógio o

crustáceo

de dentro de pólo-norte

e escudos de vidro

em dar remédio

desfechos indivisos

cirúrgicas mandíbulas

desoras antenas;

ele entranha e em torno e erra

o milagre monótono

intacto em colméias;

nem e sempre outro adeus

me não-usa, gasta o

fim não fim:

repete antecipadamente

meu único momento?

...nele

\footnotetext{
${ }^{5}$ Mas a possibilidade de uma superinterpretação não cessa de nos assombrar, razão pela qual assumimos o risco desta "Pescaria" em todo o seu potencial de desleitura errática, evocando o poema de Soares Guiamar sobre a natureza das "teses": "O peixe no anzol/é kierkegaardiano./(O pescador não sabe,/só está ufano.)//O caniço é a tese,/a linha é a pesquisa:/o pescador pesca/em mangas de camisa. [...]//O caniço, então,/se sente infeliz:/é o traço de união/entre dois imbecis..." (ROSA, 2001, p. 83).
} 
eternizo

agonizo

metalicamente

maquinalmente

sobressaltadamente

ciente.

(ARAGÃO, in: "Novas Coisas de Poesia")

Ciente está o autor de sua perversa manobra metastática ("câncer" do qual se reconhece apadrinhado "nas folhinhas" dos calendários), ao retomar sob uma oculta e degradada analogia ("Marjolininhas") a alusão às Cantigas de Amigo, especificamente às "bailías": "Correi, meninas, que o prado/pede vosso bailado.//Bailai, meninas,/eis, sim, que o prado/sempre é um chamado/por vós outras - flores,/pés multicores:/- o amor desejado/o alado. [...]" (SÂES, 2001, p. 299). Impossível não ouvir os acordes de Airas Nunes: "Bailemos nós já todas três, ai amigas,/sô aquestas avelaneiras frolidas,/e quem for velida, como nós, velidas,/se amigo amar,/sô aquestas avelaneiras frolidas/verrá bailar.[...]".

A analogia seria até honrosa, se não atentássemos para o caráter parodístico do poemachave de Soares Guiamar, o "mestre", que destitui de seu pódio canônico os românticos brasileiros; identificando-os, talvez, como "papagaios" exilados na metrópole. Relegando essa tradição à categoria de mera "parlenda" (versinhos com temática infantil e rima fácil, recitados para embalar, entreter e distrair as crianças, e que se incorporam ao repertório folclórico popular brasileiro), Guiamar contamina com o princípio corrosivo de sua ação revisionista toda a produção poética anagramática, além de criticar a precária consciência histórica do povo brasileiro. O substantivo "al" ("o mais", "o resto"), de pouco uso no Brasil, orienta a rima dominante nestes versos, que remete à "Portugal" nas palavras "real", "mal", "vegetal", "coqueiral", "desigual" e "sal"; e, em última instância, à "culpa" do poeta, que se vê comprometido na sua tarefa de administrar tão problemático espólio:

Parlenda

Papagaio foi à caça

voltou para Portugal

ausência de verdes matas

extinta raça real.

Deu voz de um príncipe louro

viagem por bem e mal.

Deixou-me suas palavras

apenas, no vegetal

caladas; ouro e segredo

um castelo e um coqueiral.

Mas a vida que me herdaram

viver, é bem desigual

- velas no mar, um degredo

e a saudade: azuis e sal.

Que eu sofra noites florestas

e minha culpa por al.

(GUIAMAR, 2001, p. 84)

O impasse da "úlcera de Marjolin" - que não cicatriza e continua a ferir numa expansão do mal que pode levar à morte - traduz-se na agudeza cáustica desses versos, em sua aparência inocentes. Um equivalente possível nas artes plásticas é encontrado na obra de Adriana Varejão, 
que utiliza um repertório similar de analogias buscado ao universo dos compêndios médicos para representar sua crítica ao imperialismo e à colonização portuguesa no Brasil: paredes azulejadas que se rasgam mostrando, como feridas abertas, suas ocultas entranhas de carne. Muitas dessas imagens - referências às produções plásticas/culturais dos artistas brasileiros educados pelo olhar colonizador - ora são dependuradas como a "caça" nas cozinhas do gênero natureza-morta, sujeitas ao revisionismo devorador e antropofágico da jovem artista carioca; ora são violentamente extirpadas e postas, como pele, sobre uma maca cirúrgica.

Resta-nos comentar sobre Sá Araújo Ségrim, "poeta comprido", "o Segredeiro”, o favorito de Guimarães Rosa. É dele o "Escólio" - comentário feito para servir ao entendimento dos autores clássicos, ou breve anotação sobre algum texto com a finalidade de explicá-lo ou torná-lo mais claro, mais compreensível; que nos serve aqui exemplarmente para finalizar este comentário:

Escólio

O que sei, não me serve.

Decoro o que não sei.

Relembro-me:

deslumbro-me, desprezo-me.

O querubim é um dragão

suas asas não se acabam.

Sempre ele me acha em falta

ou no remorso de tanta lucidez.

Somos, anciãos, amargos,

Tão amargos, juntos,

que temos de construir

do nada -

que é humano e nos envolve.

A gente tem de tirar dele

Algo, pedaço de alto:

alma, amor, praga (variante: lágrima) ou poema.

(SÉGRIM, 2001, p. 235)

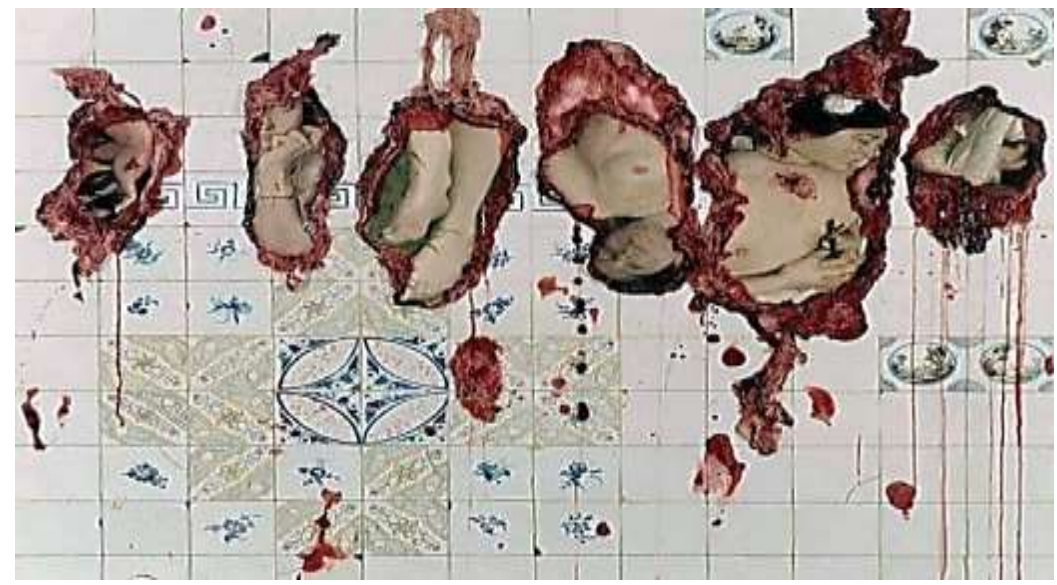

Adriana Varejão: Varejão acadêmico - Musas (1997) 


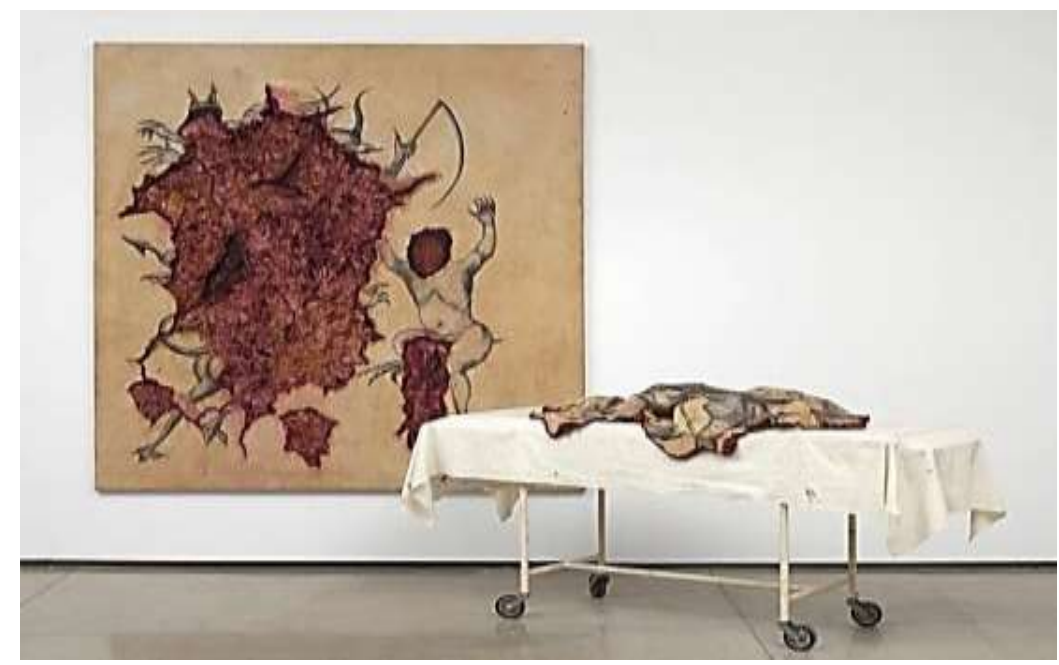

Adriana Varejão: Extirpação do mal por incisura (1994)

\section{REFERÊNCIAS BIBLIOGRÁFICAS}

BLOOM, Harold. A Angústia da Influência. Uma Teoria da Poesia. Rio de Janeiro: Imago, 1991. BORGES, Jorge Luís. Fições. São Paulo: Globo, 1989. História Universal da Infâmia. São Paulo: Globo, 1993.

DELEUZE, Gilles. Lógica do Sentido. São Paulo: Perspectiva, 1974. FERREIRA, Ermelinda. Dois Estudos Pessoanos. Recife: Edufpe, 2002. GALVÃO, Walnice Nogueira. Heteronímia em Guimarães Rosa, in: Revista USP. São Paulo (36):18-25, Dezembro/Fevereiro 1997/1998.

LOURENÇO, Eduardo. Kierkegaard e Pessoa ou a Comunicação Indireta, in: Fernando Pessoa, Rei da nossa Baviera. Lisboa: Gradiva, 2008.

PESSOA, Fernando. Ficções do Interlúdio, in: Obra Poética. Organização, introdução e notas de Maria Aliete Galhoz. Rio de Janeiro: Nova Aguilar, 1986.

ROSA, João Guimarães. Ave, Palavra. Rio de Janeiro: Nova Fronteira, 2001. . Tutaméia. Terceiras Estórias. Rio de Janeiro: José Olympio, 1967. Magma. Rio de Janeiro: Nova Fronteira, 1997.

ROOB, Alexander. Almiquia e Misticismo. O Museu Hermético. Lisboa: Taschen, 2015.

ROSSI, Érica Alves. As Poesias de Guimarães Rosa em Ave, Palavra: Um Caminho de Leitura. Dissertação de Mestrado. Faculdade de Ciências e Letras da Universidade Estadual Paulista Júlio de Mesquita Filho, Campus de Araraquara-SP, 2009.

VAREJÃO, Adriana. Entre Carnes e Mares. Rio de Janeiro: Cobogó, 2009. 